\title{
„SZUKAM PARADOKSALNEGO WYDARZENIA, A GRANICA JEST ZAWSZE PARADOKSEM..." - Z FILIPEM BAJONEM ROZMAWIA IZABELA TOMCZYK-JARZYNA
}

Izabela Tomczyk-Jarzyna: Ma Pan, jak chyba żaden z polskich twórców filmowych, olbrzymie doświadczenie w opisywaniu momentu przełomu, definiowania tego momentu. Jest Pan artystą szalenie na te kwestie wyczulonym. Czy obserwując dzisiejszą rzeczywistość, gotów byłby Pan już powiedzieć, że coś się przełamuje? Myślę o pandemii oczywiście. Czy w ogóle, żyjąc w danym momencie rzeczywistości, mamy możliwość zdefiniowania go? Pana bohaterowie to potrafią, ale oni są konstruktami, to Pan, jako twórca, określa ich możliwości.

Filip Bajon: Odpowiadając na to pytanie, trzeba byłoby sięgnąć do 1968 roku. Tak się złożyło, że byłem wówczas na Zachodzie. Jak się ta cała „wiosna paryska” zaczynała, byłem w Anglii, potem w Paryżu. I „wiosna paryska” jest pewnym takim przełamaniem epok. Wtedy naprawdę skończyła się II wojna światowa - w 1968 roku. Nastąpiło rozliczenie jednego pokolenia z następnym. Nie mówię już o narodowościach, tylko o pewnej mentalności, która spowodowała II wojnę światową, i o innej mentalności, która była rezultatem II wojny światowej. Tym stykiem jest dla mnie ' 68 rok. Oczywiście w momencie, kiedy uczestniczysz w jakichś wydarzeniach, nie masz świadomości, co one znaczą. Nie ma takiej możliwości. Ale potem, po latach, zobaczyłem „efekt “68 roku”. I w takim „efekcie '68 roku” żyłem moim zdaniem - gdzieś do roku 2015. I to w skali światowej, bo ' 68 rok to też była skala światowa, to nie była skala jednego kraju. Gdzieś w 2015 roku nastąpiła odpowiedź Historii na ' 68 rok. Odpowiedź dość spóźniona,

1 Zob. na przykład: J.P. Le Goff, Mai 68, I’héritage impossible, Paris 2006; B. Gobille, Mai 68, Paris 2018; M. de Certeau, La prise de parole, Paris 1994. 
no ale młyny historii mielą wolno. Tak to odbieram i nie mam specjalnych wątpliwości co do tego osądu. W związku z czym rok 2015 jest taką zmianą epok dla mnie zaskakującą, okazało się bowiem, że te rzeczy, które uważałem za pogrzebane, nagle ponownie się pojawiły. Myślę o nacjonalizmie, agresywny katolicyzmie, w ogóle fundamentalizmie religijnym na całym świecie, o powrocie wartości podstawowych, ale upraszczających rzeczywistość, jak oparcie się na rodzinie, oparcie się na państwie narodowym, na Panu Bogu. To wszystko było przed II wojną światową. Te źle pojmowane wartości doprowadziły do jej wybuchu i w pewnym stopniu również do wybuchu I wojny światowej. Różnica polega na tym, że pierwsza zaczęła się przypadkiem, a druga to już była zaplanowana wielka operacja, z której skutków nikt nie zdawał sobie sprawy. Jednak dokonało się to na bazie tych najogólniej rozumianych wartości. I teraz, jeżeli ja w ramach swojego życia zataczam pewne koło, to muszę powiedzieć, że jestem bardzo zdziwiony. Zastanawiam się, czy to koło każe mi na nowo przeanalizować te wartości, które wróciły, i poddać krytyce te, wśród których żyłem? Taki proces jeszcze we mnie nie nastąpił i podejrzewam, że nie nastąpi, bo jestem zbyt przyzwyczajony i identyfikuję się z liberalizmem, z tą wolnością, z tym całym majem '68. roku. Jestem $z$ tego pokolenia. Natomiast zdecydowanie następuje zmiana epok. Koronawirus jest taką plastyczną cezurą, bo jest jakiś. Przeżyłem stan wojenny, a gdy tylko nastał, natychmiast napisałem scenariusz komedii Trędowaty, której nie nakręciłem. Komuna mi ją zatrzymała w momencie, kiedy miałem rozpocząć zdjęcia. Mnie to rozśmieszyło. Stan wojenny mnie rozśmieszył, ponieważ to była agonia. To była agonia pewnego systemu politycznego. I tak to widziałem, a ponieważ powodowała różne śmieszne sytuacje, więc na tym się skupiłem. Ten film, niestety, nie powstał, gdyby powstał, poszedłby na półkę. No ale by był. Natomiast reakcja na koronawirusa jest mi jeszcze bliżej nieznana, ponieważ ja nie wiem... nikt nie wie, co się tak naprawdę stało. To, że jakiś wirus krąży, tak. Ale skąd się ten wirus wziął, dlaczego się tam pojawił i tak dalej? Tego nie wie jeszcze nikt. Nie mam skłonności do spiskowej teorii dziejów, ale w przeskoczenie z nietoperza na człowieka też nie wierzę. Nie wiem dlaczego, ale jakoś mi się to... nie składa. Może dlatego, że kiedyś byłem w umocnieniach międzyrzeckich, w których przebywa największa ilość nietoperzy w Europie, 
kręciłem tam niemiecki film fabularny Pension Sonnenschein ${ }^{2}$ i widziałem te tysiące nietoperzy... Takie śpiące, sympatyczne zwierzątka. Nie wiem... Natomiast nastąpi pewien rodzaj jakiegoś przewartościowania. To na pewno nastąpi. Tylko że mówimy tutaj o kategoriach socjologicznych - to jest czysta socjologia. Jednak żeby socjologia zamieniła się w sztukę, też musi przeskoczyć jakiś wirus , który uruchomi chorobę artystyczną. Czyli musi nastąpić moment, który potrafi skupić $\mathrm{w}$ jakiejś sytuacji, w jakimś wydarzeniu, $\mathrm{w}$ jakimś skojarzeniu, $\mathrm{w}$ jakiejś asocjacji ten proces popatrzenia na to przez obiektyw kamery. I zwykle tak bywa, że te wydarzenia, te sytuacje, które uruchamiają myślenie artystyczne - jakiekolwiek by ono nie było - zazwyczaj są peryferyjne. One nie są w mainstreamie, tylko gdzieś coś małego... I nagle okazuje się, że ma to pewną siłę uogólniającą, że ogniskuje bardzo istotne asocjacje, bardzo istotne myśli rozproszone, że potrafi to skupić w jakąś całość. Pod jednym warunkiem - że to myślenie artystyczne, które wynika z wydarzenia peryferyjnego, nie jest obciążone myśleniem-tezą. Bo jeżeli jest obciążone myśleniem-tezą, to nie jest myśleniem artystycznym. Nadal pozostaje myśleniem socjologicznym.

\section{I.T.J.: Rozumiem, że Pan próbuje się jakoś odnaleźć w tej sytuacji.}

F.B.: Zawsze próbuję się odnaleźć i nigdy nie wiem, czy mi się to udaje.

I.T.J.: A czy myśląc o tej sytuacji... bo intryguje mnie to pogranicze, które w Pana twórczości jest niesamowicie ważne, ale też rodzące pewne napięcie, czyli pogranicze między literaturą i filmem. Więc kiedy Pan próbuje określić obecną sytuację lub próbuje się w jakiś sposób do niej ustawić, czy myśli Pan o niej jako literat czy jako filmowiec? Czy w ogóle jest taki rozdział w Pana świadomości?

2 Pension Sonnenschein [Pensjonat „Słoneczko”], reż. F. Bajon, Niemcy 1990; film telewizyjny dla niemieckiej ZDF (Das Zweite Deutsche Fernsehen), kręcony w plenerach Łagowa; zob. E. Nurczyńska-Fidelska, Czas i przesłona. O Filipie Bajonie i jego twórczości, Kraków 2003, s. 126; Pension „Sonnenschein”, http://www. filmpolski.pl/fp/index.php?film=128771 [dostęp 21.05.2020]. 
F.B.: Rozmawiając z Panią, będę się starał sam siebie zrozumieć. Uważam, że pewnym tropem wiodącym do odpowiedzi na to pytanie jest fakt, że ja nigdy nie sfilmowałem żadnej swojej książki. Nigdy mnie to nie interesowało. I myślę, że to jest bardzo ważne. W jednym wypadku mam pewną pretensję do siebie, bo byłbym pierwszy - można było sfilmować Podsłuch ${ }^{3}$ o Andrzejewskim i Iwaszkiewiczu. Sytuacja była prawdziwa, bo rzeczywiście nyska stała naprzeciwko domu Andrzejewskiego i go podsłuchiwała. W mieszkaniu urządzenia podsłuchowe były za kaloryferami... Uważam jednak, że nie myślę ani literaturą, ani filmem, myślę rzeczywistością. Nieoczekiwanie - rzeczywistością. Jeżeli znajdę jakiś taki paradoks w rzeczywistości, to zaczynam się nad nim zastanawiać. I gdzieś intuicyjnie, bo nie mam żadnej specjalnej aparatury, wiem, czy z tego powinna powstać książka, czy też z tego powinien powstać film. Ponieważ literatura mnie dość drogo kosztowała, powiedziałbym: w kategoriach psychicznych, to podziwiam literatów, wielkich pisarzy, którzy pisali przez całe życie. Niedawno uświadomiłem sobie, że Józef Hen pisze już 74 lata. To jest taki wysiłek - pisanie. To nie są bohaterowie słowa, tylko bohaterowie wielkiego psychicznego wysiłku. Wyniszczającego wysiłku, bo pisanie wyniszcza. Natomiast filmowanie buduje. Oczywiście są filmowcy wielcy, którzy nie lubili filmować, źle się czuli, kiedy filmowali. Lepiej się czuli, gdy siedzieli w montażowni czy pisali scenariusz. Ale to wszystko zależy od temperamentu. Jeszcze raz mówię: szukam paradoksalnego wydarzenia, a granica jest zawsze paradoksem, bo tak naprawdę nie powinno być granic. Kiedyś nie było żadnych granic. Potem były granice i też taka granica, jak na Piaśnicy,

3 Filip Bajon mówi o uprzedniości swojego pomysłu (powieść Podsłuch została wydana w 1994 roku przez warszawskie wydawnictwo Tenten) w stosunku do filmu z 2006 roku Życie na podstuchu w reżyserii Floriana Henckela von Donnersmarcka. W 2007 roku film otrzymał Oscara w kategorii najlepszy film nieanglojęzyczny.

4 „Słupek graniczny nr 1 przy ujściu Piaśnicy do Bałtyku wyznaczał północno-zachodni kraniec Polski. Miejsce to było [...] celem wycieczek Polaków szczęśliwych z powodu uzyskania przez Rzeczpospolitą dostępu do morza. $\mathrm{Na}$ słupku widnieje data i miejsce podpisania Traktatu Wersalskiego ustanawiającego granice po I wojnie światowej"; http://muzeumpiasnickie.pl/news/27-piasnica-rzeka-przygraniczna-ii-rzeczypospolitej [dostęp 25.05.2020]. Piaśnica - wieś, przez którą przepływa rzeka o tej samej nazwie - jest niezwykle istotnym miejscem dla 
przed wojną, między Polską a Niemcami. Teraz rzeczka sobie płynie i można się w niej wykąpać, wpada do morza. A była to bardzo znacząca granica, która dzieliła ludzi, która określała losy ludzkie, dzieliła majątki i tak dalej. Ta granica jest takim pewnym paradoksem dziejącym się w rzeczywistości, dlatego mnie to gdzieś, myślę, uderzało. Kiedy ja dojrzewałem, nikt nie mógł myśleć o Europie bez granic, ale proszę zwrócić uwagę, że w momencie kryzysowym wróciliśmy do granic, wróciliśmy do starych sprawdzonych formuł. Nagle okazuje się - z czego się nie cieszę, ale widzę to - że wszyscy odwołują się jednak do struktury państwa narodowego, a nikt nie odwołuje się do struktury federacyjnej. Bo struktura federacyjna - analizy nastąpią za kilka miesięcy - prawdopodobnie mogła okazać się organizacyjnie za słaba w sytuacji, kiedy trzeba było zadziałać szybko i zdecydowanie. Czyli obecnie możemy sobie powiedzieć, że jesteśmy w momencie granicznym. Oczywiście te nawroty prawicowości, te nawroty faszyzacji i tak dalej opisał już na przykład Günter Grass w powieści Idąc rakiem (Zum Krebsgang), gdzie mówi o nowym narodzeniu się prawicowości w Niemczech. Czytałem to zafascynowany, bo wiedziałem, że on dostrzegł wcześniej coś takiego, czego ja nie dostrzegłem, i potrafił to fantastycznie opisać. Zresztą wielokrotnie taka zazdrość o dzieło była pewnym motorem mojego działania. U kogoś coś dostrzegłem, to zaczynałem się zastanawiać: a gdzie to jest w moim otoczeniu, gdzie to istnieje. I myślę też, że ważną sprawą w tym moim patrzeniu było to, że - i nie wiem, z czego to mam, nigdy nad tym nie pracowałem - że mam pewną niechęć do realizmu, że interesuje mnie bardzo wysoki realizm. Być może, że mam coś przestawione w postrzeganiu

akcji Kamerdynera, filmu Bajona z 2018 roku. Reżyser powraca w symbolicznych scenach do egzekucji dokonywanych na ludności Pomorza od września 1939 do pierwszych miesięcy 1940 roku. „Piaśnica stanowiła swoisty teren eksperymentalny, ponieważ tutaj po raz pierwszy w Polsce zostały przeprowadzone planowane masowe zbrodnie na ludności cywilnej"; M. Tomkiewicz, Zbrodnia w Piaśnicy, [w:] Przewodnik. Piaśnica. Miejsce niemieckich zbrodni na Pomorzy w 1939 roku, oprac. M. Odyniecki, J. Józefczyk, Wejherowo 2017, s. 4. O tych wydarzeniach mówi również - w promującym film cyklu: Historia Polski w filmie „Kamerdyner” - Janusz Gajos, grający postać Bazylego Miotke; zob. Historia Polski w filmie „Kamerdyner”, cz. 2: Piaśnica - pierwsze ludobójstwo II wojny światowej; https://www.youtube. com/watch?v=aqjiv9WQA14 [dostęp 23.05.2020]. 
świata, że mały realizm mnie kompletnie nie interesuje. Nie interesują mnie małe historyjki z życia, że ciotka... a tu babcia... a tu wujek... i okazuje się, że było nieślubne dziecko, i tak dalej. Ale częstokroć się zastanawiam, czy czegoś nie tracę.

I.T.J.: Magnat, film z 1987 roku, i Kamerdyner - Pana ostatni film, to dwie wielkie historie, w których dotyka Pan między innymi problemu przełomu, przewartościowania się w historii. Mówiąc o Kamerdynerze, wspominał Pan o tym, że ten tytuł spodobał się Panu dlatego, że postać kamerdynera nie jest jednoznaczna. Czy tak samo jest z Magnatem? Czy tytuł Magnat jest wskazaniem palcem jednego $\mathrm{z}$ bohaterów?

F.B.: Jak wymyślałem Magnata, to jednak ze względu na Janka Nowickiego. $\mathrm{Na}$ nim budowałem tę całą konstrukcję. Pamiętajmy o tym, że Janek grał Stawrogina kiedyśs. A na czym polega figura Stawrogina? Na tym, że Stawrogin sam wybiera, czy chce być dobry, czy zły. To jest sprawa jego wyboru. Mówi: „dzisiaj będę zły”, a następnego dnia mówi: „a dzisiaj będę dobry; dziś będę Mefistofelesem, dziś będę Panem Bogiem”. I tak samo konstruowałem Janka, znając tego Stawrogina i znając jego wewnętrzne upodobanie do zła. Janek prywatnie jest uroczym, wspaniałym człowiekiem, bardzo go kocham. Chodzi mi o takie upodobanie do ciemnej strony rzeczywistości. On to bardzo lubi, dlatego go obsadziłem. Wszyscy byli zdziwieni, że go obsadziłem.

I.T.J.: A Jan Englert? Przyznam, że nie do końca zgadzam się z opinią Eweliny Nurczyńskiej-Fidelskiej, która określa jego kreację jako „najmniej wyrazistą aktorsko rolę" . Moim zdaniem Englert zagrał wbrew własnym warunkom i wbrew wyobrażeniu widzów, którzy kojarzyli go przecież z cieszącym się niesamowitą popularnością serialem $\mathrm{Dom}^{7}$.

${ }^{5}$ Chodzi o teatralna adaptację Biesów w reżyserii Andrzeja Wajdy. Spektakl wystawiany był w Narodowym Starym Teatrze im. Heleny Modrzejewskiej w Krakowie i miał swoją premierę 29 kwietnia 1971 roku.

6 Zob. E. Nurczyńska-Fidelska, op. cit., s. 119.

7 Serial w reżyserii Jana Łomnickiego miał swoją premierę w 1980 roku. Seria pierwsza to siedem pierwszych odcinków, seria druga, która w Telewizji Polskiej 


\section{Udało mu się w tej kreacji nie dotknąć granicy przesady. Czy Pan był zadowolony $\mathrm{z}$ efektu?}

F.B.: Tak, byłem bardzo zadowolony. Trochę mi - powiedziałbym - Englerta podpowiedziała jego rola w Barytonie Janusza Zaorskiego ${ }^{8}$, gdzie tak delikatnie zagrał homoseksualistę. Tak sobie pomyślałem, że tutaj może by bardzo pasował. I też miałem wrażenie, że jeszcze Janek nie pokazał wszystkiego, na co go stać. Ta rola trafiła. Zresztą taka sytuacja obsady... trochę miałem szczęście, bo to była końcówka stanu wojennego i aktorzy nie byli jeszcze tak bardzo pozajmowani, tak że mogłem zrobić taką konfigurację, jaką chciałem. Ale i tak w scenie kolacji rodzinnej, tej pierwszej duże scenie, gdzie nastąpiło rozdanie kart, nigdy wszystkich nie miałem przy stole. Musiałem kręcić na strony. Przerwy między niektórymi ujęciami były rzędu kilku miesięcy.

\section{I.T.J.: To chyba ciężka praca, kiedy trzeba po tak długim czasie ponownie wchodzić w ten sam moment?}

F.B.: To aż tak ciężkie nie jest, tylko trzeba pamiętać wszystko. Ponieważ jednak przetrenowałem to w Magnacie, w Kamerdynerze było mi łatwiej. Pięć podejść do zdjęć. To jednak klarowało pewne sprawy i pewne sprawy z powodu tych przerw się wyjaśniały. Inna kwestia, że jak reżyser ma dużo czasu, to ma i dużo pomysłów. $Z$ tego powodu producenci tak skracają okres zdjęciowy.. A w trakcie realizacji tego filmu mieliśmy z Guttem ${ }^{9}$ dużo czasu i mogliśmy wymyślać.

pokazywana była w 1982 roku, obejmowała odcinki od ósmego do jedenastego. Zrealizowano jeszcze dwie serie, które przedstawiono publiczności odpowiednio w 1996 i 2000 roku. W roku premiery Magnata (1987) Telewizja wyświetliła jeszcze dodatkowy odcinek pt.: Kto dziś tak umie kochać, który miał zamykać całość historii; zob. http://www.filmpolski.pl/fp/index.php?film=123457 [dostęp 17.04.2020]. Englert został obsadzony w roli reżysera dokumentalisty Rajmunda Wrodka, lekkoducha, który damsko-męskie relacje sprowadzał zwykle do określenia: „riki tiki tak".

8 Baryton, reż. J. Zaorski, Polska 1984.

9 Łukasz Gutt - operator; z Filipem Bajonem współpracował również przy realizacji filmu Panie Dulskie (2015). 
I.T.J.: Mówi Pan o tym, że Magnat to jednak Jan Nowicki i jego postać. Zresztą Nurczyńska-Fidelska, kiedy analizuje ten film, zauważa, że to on jest opowiadaczem, to on jest narratorem. Rzeczywiście, ten moment, kiedy książę mówi, że dźwięk syren być może przywoła jego synów, potwierdza to spostrzeżenie. Pojawiają się obrazy tych chłopaków, które ojciec niejako swoją pamięcią przywołuje...

F.B.: Tak.

I.T.J.: Postać magnata jest elementem konstrukcyjnym tego filmu, w jakimś sensie stałym. Mam wrażenie, że są w tym filmie takie elementy, które znaczeniowo się zmieniają, na przykład: rodzina. Dla mnie Magnat nie jest tylko opowieścią o relacjach i więzi krwi; wydaje mi się, że ta rodzina jest znacznie szerzej przez Pana rozumiana?

F.B.: Oczywiście, że rodzina, ale rodzina oczyma Janka Nowickiego, rodzina w rozpadzie, a rozpad jest zawsze czymś szerszym.

I.T.J.: Postaciami, które nadają dynamizm temu terminowi, są książę i jego syn Franzel. To są postaci, które po swojemu próbują zdefiniować, czym jest rodzina, i definiują to bardzo różnie.

F.B.: Franzel definiuje rodzinę jako rygor, a Janek definiuje rodzinę jako wolność. Franzel mówi: rodzina jest rygorem, w rodzinie nic nie można, rodzina musi pracować na swoją wielkość. On działa na zasadzie: „Ja was wszystkich złapię za mordę i utrzymam, i wtedy nam się uda, nam jako rodzinie”. Mamy tutaj przykład myślenia, o którym mówiłem na początku, myślenia sprzed 1933 roku. Tam jest jeszcze jeden element; otóż Janek uważa, że zna dalszy ciąg dziejów swojej rodziny. On wie, co się zdarzy. I on wie, że to wszystko jest skazane na klęskę. Wie, że to się Franzlowi nie uda, że nikomu się nie uda. Książę mówi, że mógłby być królem Śląska on rzeczywiście tak kombinował, tak myślał, ale wiedział, że to się nie zdarzy. Myśli też, że wie, co się zdarzy, i mówi: „No dobrze, to jak Pan Bóg będę się temu przyglądał, jak to się wszystko rozwala na moich oczach". Tylko nie przewiduje jednej rzeczy: hitleryzmu. Bo tego nie przewiduje. Nie przypuszcza. 
I.T.J.: Tak. Do tego się też przyznaje.

F.B.: Tak, nie przewiduje i na to reaguje. Natomiast na wszystkie inne sprawy, które dewastują rodzinę, nie reaguje, tylko patrzy na to z góry i jak Pan Bóg myśli: „No, czyli idzie to po mojej myśli. Idzie po mojej myśli wszystko, piękny koniec będzie”. Ale hitleryzmu nie przewidział i musiał się do tego odnieść jako przedstawiciel odchodzących wartości, musiał przeciwko temu zaprotestować.

I.T.J.: Jest jeszcze jeden taki moment, kiedy książę von Teuss staje przed górnikami i mówi: „Jesteśmy rodziną!”, na co mu górnicy odpowiadają...

F.B.: „Jaka my rodzina?”.

I.T.J.: Tak, i po jakiemu nas biją. To mu się nie udaje. Odnoszę wrażenie, że bohater Nowickiego próbuje przełożyć swoje rozumienie rodziny na szerszą skalę i to mu nie wychodzi.

F.B.: Ale to było myślenie $\mathrm{z}$ tamtej epoki. Fabryka to jest rodzina, to wszystko - nawet miało swoją nazwę, taki kapitalizm... „Falanstery” chyba. W Anglii wspólnoty takie istniały, nawet równo się zyskiem dzielono i tak dalej, takie utopie.

\section{I.T.J.: Czyli on w to wierzył? To było z jego przestrzeni?}

F.B.: Tak.

I.T.J.: Myślę jeszcze o dwóch takich rzeczach, które mi w jakiś sposób porządkują Magnata. Nie wiem, czy to też było w Pana zamierzeniu. Myślę o czasie, który w wersji kinowej ${ }^{10}$ jest bardziej intrygujący, i myślę też o sposobie pokazywania granic, które moim zdaniem są bardzo różnie rozumiane. Nie chodzi wyłącznie o granice państw, które się zmieniają, bo obserwujemy kilkadziesiąt lat $z$ dziejów Europy, ale chodzi mi też

10 Film Magnat miał również swoją wersję telewizyjną - w 1989 roku widzowie mogli obejrzeć sześcioodcinkowy serial pt. Biała wizytówka. 
o granice, które dokonują się w rodzinie i dokonują się w ramach poszczególnych postaci. Franzel takiej granicy dotyka. Jak Pan wymownie o nim powiedział: „Zwariować z normalności”. Okazuje się, że normalność też może być poza progiem bezpieczeństwa.

F.B.: Ale nich Pani zwróci uwagę, że teraz, po 2015 roku, pewne środowiska wariują z normalności właśnie. To się powtarza,

I.T.J.: Tak, powtarza się. Bardzo też podobał mi się sposób pokazywania przestrzeni pałacowych, które są fotografowane głębią ostrości. Pomyślałam, że jest to sposób na pokazanie w warstwie wizualnej przestrzeni rodzinnej. Przechodzenie bohaterów przez kolejne pokoje to jak przekraczanie kolejnych granic. Jak ta scena, w której Franzel dowiaduje się, co go czeka, gdy okaże się, że pomagał hitlerowcom: w szale biega po całym pałacu i woła brata. Relacje w rodzinie przekładają się na przestrzeń.

F.B.: Parę fragmentów pałacu pokazałem jeden jedyny raz - w tej właśnie scenie. Więcej ich nie pokazywałem, z różnych powodów. Niby mogłem się poruszać, ale w pałacu były jednak pewne obostrzenia. Tak naprawdę wiedziałem, że będę miał taką scenę, w której będę mógł pokazać pałac w całości. Tak dygresyjnie powiem Pani, że - to odkryłem dopiero przy Kamerdynerze i w Magnacie zrobiłem ten błąd - jak robi się taki film w pałacu, to przypisuje się pewne miejsca bohaterom: to jest gabinet księcia, to jest sala jadalna, to jest sala balowa, a to sypialnia książęca. I tak zrobiłem w Magnacie. Scenografowi powiedziałem: tu, tu, tu. Potem jednak się zorientowałem, że jeżeli chcę ten film zrobić, to nie mogę się tego trzymać. Uświadomiłem sobie, że jest właściwie jedno wnętrze: pałac. I nie ma innych. W związku z czym scenografowie dostali szału, bo pourządzali mi różne klitki-klatki, a ja powiedziałem: nie. Łóżko tu będzie, gdzie kamera chce, a nie zgodnie z logiką mieszkańców. I w Magnacie też tak zrobiłem, że podzieliłem przestrzeń i potem podświadomie - bo teraz to już wiem, co zrobiłem, ale wtedy nie wiedziałem - zacząłem ją traktować jako pałac. A to mogę przecież tu nakręcić - bo świetna jest ta klatka schodowa - zatem tu to zrobimy! Tak więc funkcjonalny podział dużego wnętrza się nie sprawdza, bo wiąże ci ręce. Wiąże ręce mnie jako filmowcowi, jeżeli rzecz dzieje 
się np. w małym gabineciku księcia, a przecież to biurko można przenieść, gdzie się chce, postawić, gdzie się chce. Można mieć fantastyczną przestrzeń. Czasem więc reżyserzy nakładają na siebie takie pułapki, ale to też wynika z pewnej struktury porozumiewania się, bo muszę powiedzieć scenografowi, co ma robić. On musi wiedzieć: „a co ja teraz urządzam?”. Myśmy czasami korzystali z tych małych wnętrz, ale w porównaniu z tym, co było zaplanowane, to w 2-3 procentach. Generalnie grałem całą przestrzenią. No bo jak pałac, to już pałac (uśmiech).

I.T.J.: Może to jest kwestia jakości zdjęć i sposobu filmowania w latach 80. i obecnie, niemniej wrażenie wizualne, jakie daje pałac, który udało się Państwu wynaleźć do realizacji Kamerdynera, jest olbrzymie.

F.B.: Mało jest takich pałaców niezniszczonych. Bardzo mało.

\section{I.T.J.: Długo Państwo szukaliście miejsca do zdjęć?}

F.B.: Kiedy dołączyłem do projektu, pałac był już znaleziony. Miał bardzo wiele dobrych stron: należał do Uniwersytetu Warmińsko-Mazurskiego ${ }^{11}$, nikogo nie było, tylko konferencje się tam odbywały. Miał dużo takich atutów, które dawały wolność. Wolność była właściwie stuprocentowa, mogliśmy robić wszystko, co chcieliśmy. Nie ma tych pałaców, bo je niszczono albo są nieprzydatne do zdjęć filmowych. Jest pałac von Below w Rzucewie niedaleko Pucka, ale to nie to. Natomiast ten rzeczywiście świetnie się fotografował.

\section{I.T.J.: Chciałabym jeszcze chwilę porozmawiać na temat Pana koncepcji} czasu w Magnacie. Ta decyzja o tym, że historia nie będzie chronologicznie opowiedziana, zwraca uwagę widza, musimy się przyzwyczaić do tego, że co chwilę jesteśmy w innej przestrzeni historycznej, ale to nie

11 Pałac w Łężanach wybudowano w latach 1909-1911, jego pierwszym właścicielem był Reinhold von Fischer-Lossainen. W drugiej połowie lat 50. budynek został przekazany Wyższej Szkole Rolniczej w Olsztynie, po okresie dzierżawy przez osobę prywatną (lata 90.) pałac ponownie przejęła uczelnia; http://www. uwm.edu.pl/lezany/ [dostęp 22.05.2020]. 
powoduje niezrozumienia tej historii. Dlaczego taka decyzja? Dlaczego Pan się zdecydowal, aby właśnie w ten sposób pokazać czas?

F.B.: To właściwie nie ja wymyśliłem, tylko historia, którą opowiadam, wymyśliła, ponieważ scenariuszowo nie dawało się to napisać chronologicznie. Dochodziłem, nie wiem, do dwudziestej strony i przestawałem pisać. Nie dawała się opowiedzieć. Potem w serialu dała się, o dziwo, zmontować chronologicznie bez żadnych problemów. A wersję scenariusza, kiedy wpadłem na pomysł, żeby nie opowiadać tego chronologicznie, napisałem w miesiąc. A kiedy pisałem chronologicznie, to trzy miesiące się męczyłem i odrzucało. Jak to ktoś powiedział: „historia ma rację”. Zresztą zauważyłem, że historie jakby chcą być opowiadane w pewien sposób, a jak są gwałcone, to się bronią.

I.T.J.: I to jest niesamowite, bo okazuje się, że taki sposób opowiadania powoduje, że historia staje się wielowymiarowa. Ja na przykład uświadomiłam sobie, że na nowo odkrywam znaczenie niektórych fragmentów. Kiedy Franzel pierwszy raz wchodzi do biura kopalni, wprowadzając swoje porządki, nakazuje, aby zabrać stamtąd fontannę, bo to nie jest dla niej miejsce. Na logikę przyznałam mu rację. Kilka scen później pokazuje Pan jednak, że ona ma swoje uwarunkowanie, ona jest potrzebna, a decyzja Franzla dewastuje cały dotychczasowy porządek. Taka konstrukcja czasu wymusza, aby historię obejrzeć do końca, nie podejmować decyzji dotyczących rozszyfrowywania znaczeń, dopóki film się nie skończy.

F.B.: To tak powiem gwoli faktów, że najpierw napisałem tę opowieść niechronologicznie, tak jak widać to $w$ filmie. Tak ją napisałem, bo tak się dała napisać. Potem wyjechałem do Londynu i tam, w British Museum Library, znalazłem pamiętniki Daisy ${ }^{12}$, których nie znałem wcześniej, fragmenty tylko czytałem. Siedziałem tam dwa tygodnie. Ponieważ nie można było kserować, to notowałem, notowałem... I kiedy przeczytałem te pamiętniki,

12 Daisy, Princess of Pless, By Herself, London 1928; eadem, From My Private Diary, London 1931; eadem, What I Left Unsaid, London 1936; polskie wydania: Daisy Hochberg von Pless, Taniec na wulkanie 1873-1918, tłum. M. Palcewicz, Kraków 2002; eadem, Lepiej przemilczeć, tłum. B. Borkowy, Wałbrzych 2013; eadem, Co przemilczałam, tłum. B. Borkowy, Wałbrzych 2019. 
napisałem chronologiczną, tym razem, wersję scenariusza. Ponieważ Daisy dała mi dużo informacji, rozszerzyłem to na sześciogodzinny serial. Potem pojechałem raz jeszcze na dokumentację. Przecież fontanny w scenariuszu nie było, tego wnętrza, jak on przechodzi i uderza, i jak tablica spada ${ }^{13}$, ten włącznik syreny... Dostrzegłem to dopiero, jak zobaczyłem wnętrze, które mogłem przerobić tak, jak chciałem. Wówczas właśnie powstała ta fontanna i te inne elementy. Jednak najpierw pojawiły się one w rzeczywistości, bo mi to scenograf zbudował. Sprawdziłem, jak to działa, potem przeniosłem do scenariusza i to była, że tak powiem, trzecia wersja scenariusza, którą uzupełniłem o to, co zobaczyłem. To, że książę się zapada wziąłem z przeczytanych wycinków z prasy dziewiętnastowiecznej ze Śląska. Opisywano tam historie, w której nagle znikały krowy na polu. Stała krowa - nie ma krowy. To mi się strasznie spodobało, więc też to wsadziłem. Czyli były trzy redakcje: jedna tak, jak historia sama chciała się ułożyć, potem przyszły dzienniki Daisy - i ona zaczęła być ważniejszą postacią - i chronologicznie dały mi one materiał na serial. Też tam dopiero wprowadziłem tak mocnego Heinberga, w tej drugiej wersji - w pierwszej wersji Heinberg nie był tak mocną postacią. Tak więc wprowadziłem tego Heinberga, a to się wzięło też z tego, że pojechałem i zobaczyłem Świerklaniec Donnersmarcków. Dowiedziałem się, że o ile Plessowie, jak weszli hitlerowcy na Śląsk, uciekli, to Donnersmarckowie witali ich chlebem i solą. Pomyślałem, że taki Donnersmarck mógłby być w opozycji do księcia przez cały film. I tak powstał Heinberg, i tak wyciągnąłem tego Rolfa Hoppego z Mefista ${ }^{14}$ i przeniosłem do mojego filmu. Tak że to powstawało etapami. Był stan wojenny, nie można było rozpędzić takiego filmu. Zresztą ustawienie finansowe tego filmu było bardzo trudne. Bardzo mi wtedy Rywin ${ }^{15}$ pomógł, który był w telewizji. W każdym razie to było takie etapowe dochodzenie do finału.

13 Mowa o scenie, w której Franzel, uderzając w poręcz, sprawia, że ze ściany spada drewniana tablica.

${ }^{14}$ Mefisto, reż. István Szabó, Węgry 1981. Rolf Hoppe odtwarzał w filmie postać nazistowskiego generała.

${ }^{15}$ Lew Rywin (ur. w 1945) - producent filmowy. W czasie, gdy powstawał Magnat, Rywin był dyrektorem Centralnej Wytwórni Programów i Filmów Telewizyjnych „Poltel”; http://www.filmpolski.pl/fp/index.php?osoba=1116270 [dostęp 27.04.2020]. 
I.T.J.: Bardzo ciekawie zaczyna się ten film: mamy zdjęcia z epoki, zdjęcia, które się zmieniają na tle napisów początkowych, z kolei elementem, który zamyka, jest projekcja kroniki rodzinnej. Pomyślałam, że te zdjęcia, które rozpoczynają historię, one też zwiastują, co się za chwilę wydarzy. Zapowiadają opowieść o końcu. Roland Barthes ${ }^{16}$ mówił, że w zdjęciu jest ślad śmierci.

F.B.: Znam tę książkę.

I.T.J.: Ten film pokazuje, że próbujemy dotknąć czegoś, czego już nie ma, i te fotografie są takim znakiem odchodzenia. No i kronika, która zamyka całą historię. Dlaczego Konrad, oglądając stare filmy, mówi: „Nie pamiętam"?

F.B.: To jest takie moje przekonanie, że się nie pamięta. Nic się nie pamięta. Pamięć w ogóle to jest bardzo zajmująca sprawa. Jako materia i literatury myślę że przede wszystkim literatury, może trochę filmu. Ale pamięć jest zawsze nieprawdziwą rekonstrukcją. Nie ma prawdziwej pamięci, pamięć jest zawsze fałszywa. Moja ostatnia niewydana powieść: Przedstawienie, przedstawienie (fragment był w „Twórczości”17) jest właściwie o pamięci. No, jeżeli ktoś inteligentny to przeczyta (śmiech), to zrozumie. Uważałem, że to jest bardzo dobry pomysł na zakończenie: „nic nie pamiętam”.

I.T.J.: Rozumiem, że dla niego oglądanie tego, co zostało zarejestrowane kilkadziesiąt lat wcześniej, to jest jak oglądanie zupełnie innej rzeczywistości?

F.B.: Zupełnie innej rzeczywistości. Było inaczej, było szerzej, było zupełnie inaczej. A ta kronika - jej nie było w scenariuszu.

\section{I.T.J.: Więc skąd pomysł?}

16 R. Barthes, Światło obrazu. Uwagi o fotografii, tłum. J. Trznadel, Warszawa 2008, s. 163 i n.

17 F. Bajon, Route 99, „Twórczość” 2016, nr 1, s. 8-46. 
F.B.: Pomysł się wziął z tego, że miałem drugiego reżysera ${ }^{18}$ i drugi reżyser czuł się niedowartościowany, i drugi reżyser miał kłopoty ze swoim małżeństwem, i nawet chciał zabić siekierą swojego konkurenta. Zjechał mi z planu. Potem wrócił na plan. Opowiedział mi to i wrócił na plan. Ale czułem, że coś powinienem mu dać. I mówię: „Słuchaj, może byś zaczął kręcić kronikę tej rodziny. Taką dokumentalną”. Bo tam był fotograf tej rodziny. Ja mówię: „Gdyby ten fotograf kręcił więcej i ty byś był tą kamerą, którą widzieliśmy, i kręcisz różne sceny”. Zabierał mi aktorów i ustawiał. Ja w to w ogóle nie ingerowałem, on kręcił swoją własną kronikę tej rodziny. Przyjechał Daniel Olbrychski, wziął Daniela, Churchilla i zrobił Daniela z Churchillem, a tutaj $\mathrm{Olo}^{19} \mathrm{z}$ pieskiem. Ola z pieskiem to chyba mu zasugerowałem, ale generalnie miał wolną rękę. Sceny powstańcze, Trelę... Miał prawo kręcić, co chce, i to się bardzo przydało, zwłaszcza w serialu, bo w filmie chyba nie ma kronik...

\section{I.T.J.: Są na samym końcu, zamykają film.}

F.B.: Zamykają, tak. Są, te trzy ujęcia. On jest coraz dalej, coraz dalej, coraz dalej. Natomiast w serialu otwierają każdy odcinek. I wchodzą, i pokazują... Bardzo to serial ubarwiło.

I.T.J.: Mam też wrażenie, że to metafilmowo bardzo zagrało. Opowiada Pan historię, posługując się wyspecjalizowanym językiem filmu, zaczynającą się w 1900 roku i kończącą po II wojnie światowej. Obejmuje więc czas, kiedy kino nabierało rozpędu, zaczynało uczyć się wykorzystywać własny język do tworzenia fabuł. Kolejny element, który pokazuje, że opowiada Pan o rzeczywistości w wielu perspektywach.

${ }^{18}$ Jerzy Moniak (1947-2010) - II reżyser, kierownik produkcji; z Filipem Bajonem współpracował przy realizacji Magnata i Białej wizytówki, ale również takich filmów, jak: Wizja lokalna 1901 (1980), Wahadełko (1981), Limuzyna DaimlerBenz (1981), Engagement (1984), Bal na dworcu w Koluszkach (1989), Sauna (1992), Lepiej być piękna i bogatą (1993), Poznań 56 (1996).

19 Olgierd Łukaszewicz wcielił się w postać Franzela, syna Hansa Heinricha. 
F.B.: Proszę zobaczyć, jak szeroko był to pomyślany film. Ja zawsze mówiłem, że strasznie chciałbym zrobić film, który jest mądrzejszy ode mnie, szerszy. Taki film, którego ja nie jestem w stanie pojąć. I to w Magnacie się zdarzyło, że ja mogłem w połowie filmu puścić, że tak powiem, film w filmie, który tylko ten film wzbogacił, dodał nowego spojrzenia. I że to było możliwe, czyli film był tak szeroki, że przyjmował dodatkowe elementy. Przyjmował ciało obce, które nie podlegało żadnej weryfikacji dramaturgii, obsady, treści, fabuły. Było kompletnie takim ciałem bezinteresownym, które zaistniało.

I.T.J.: Co w takim razie zaważyło na tym, że po latach zdecydował się Pan wrócić do przełomu 1900 roku. Zrobił Pan doskonały film. NurczyńskaFidelska o Magnacie pisze: „Biała wizytówka, a zwłaszcza Magnat, to filmy, które zajęły w historii polskiego kina miejsce na pierwszych jej stronach”20. Kończąc rozdział o Magnacie, podsumowuje: „Realizując swój film, Filip Bajon okazał się - zwłaszcza w formule Magnata - mistrzem klimatu światów, które odchodzą, ale także przenikliwym ich historiozoficznym interpretatorem. To, co miało początek w Arii dla atlety $^{21}$, Wizji lokalnej $1901^{22}$ i po części także w Limuzynie DailmmerBenz $^{23}$, znalazło swoje zwieńczenie w Magnacie, najwybitniejszym jego filmie, jednym z najpiękniejszych i najmądrzejszych w europejskim kinie" $^{24}$. Stworzył Pan arcydzieło. Nie miał Pan tremy, zaczynając prace nad Kamerdynerem?

F.B.: Miałem tremę, oczywiście, że miałem tremę, bo miałem tę świadomość. W tym wypadku zadecydował element sentymentalny. Znam Kaszubów, przyjaźnię się z nimi - niezależnie od filmu - od wielu, wielu lat. I miałem niesamowity sentyment do nich, do tej ziemi, do ich historii. Kiedyś chciałem robić film dokumentalny. Myślałem o tym, żeby nakręcić rok w Jastarni. Gdybym miał znowu coś realizować na Śląsku, to bym nie kręcił. I znowu miałem tę możliwość, że dostałem scenariusz, ale mogłem

20 E. Nurczyńska-Fidelska, op.cit., s. 99.

${ }^{21}$ Aria dla atlety, reż. F. Bajon, Polska 1979.

22 Wizja lokalna 1901, reż. F. Bajon, Polska 1980.

23 Limuzyna Daimler-Benz, reż. F. Bajon, Polska - RFN 1981.

24 E. Nurczyńska-Fidelska, op. cit., s. 125. 
sięgnąć do pamiętników Otto Bismarcka. Zgniłe kartofle się przecież stamtąd wzięły. Mogłem sięgnąć do hrabiny Dönhoff ${ }^{25}$. Chciałem kiedyś robić film o hrabinie Dönhoff, napisałem 80 stron scenariusza. Nie był skończony. Zaczynał się w Sztynorcie, miał się kończyć na targach książki we Frankfurcie nad Menem. Było zesłanie w Kazachstanie, byli baptyści i tak dalej. No ale niestety to był dość drogi film, zmarł producent w Niemczech Zachodnich i nigdy filmu nie zrobiłem, a scenariusz w tajemniczych okolicznościach zniknął. Tylko jego fragmenty mam. Tak że byłem dość obeznany, że tak powiem, ze statusem Prus Wschodnich, czym to było i z czym to się jadło. Jadło się zgniłe kartofle, to była biedna ziemia. Te pałace były dość od siebie odległe, co oni mogli tam robić? Uprawiać szóstej klasy glebę, mogli pójść w dyplomację i zostać, nie wiem... posłem w Waszyngtonie czy w Petersburgu albo na dworze cesarza Wilhelma. To były trzy możliwości. To był pewien rodzaj biedy. I - że tak powiem - tak oczywiste zmiany granic, zmiany ich sytuacji... Ale niech Pani zwróci uwagę, że nikt się nie dopatrzył, że to jest film o niemieckiej rodzinie...

\section{I.T.J.: Tak, to prawda, film funkcjonuje jako opowieść o Kaszubach. A co z serialem?}

F.B.: Czekam od ponad roku na informację. Już miałem zaczynać montować, jest inna wersja, inaczej ma być opowiadana, ale nie dostałem strzału startowego.

\section{I.T.J.: Kiedy opowiada Pan o Kamerdynerze, to mówi, że tym, co Pana interesowało przede wszystkim $w$ tej historii, jest czas.}

F.B.: No tak, bo jak mnie Fabijański (Sebastian) pytał, jak ma grać i kto jest bohaterem właściwie w tym filmie, to ja mu mówiłem: „Słuchaj, to jest film

${ }^{25}$ Marion hrabina Dönhoff (1909-2002) - publicystka, autorka artykułów prasowych i 25 książek. Jej teksty dotyczyły przede wszystkim oporu wobec Hitlera, pojednania Niemiec z krajami Europy Wschodniej oraz krytyki kapitalizmu; zob. T. Sommer, Kobieta o wyjątkowej osobowości, http://fwpn.org.pl/assets/dowloadable_files/die20zeit20nr2012.pdf [dostęp 22.04.2020] oraz: http://www.marion-doenhoff.de/?seite $=$ stifterin $\&$ sprache $=$ pl [dostęp 22.04.2020]. 
epicki, a w filmie epickim bohaterem jest czas”. I odchodził (śmiech). Tak jak mówię: pamięć i czas to są dwie rzeczy, które... ponieważ nie potrafię ich zdefiniować, to sobie robię prywatne badania nad tymi zjawiskami.

I.T.J.: Ale subtelniej Pan dotyka czasu w Kamerdynerze niż w Magnacie. W Magnacie - mówię o wersji kinowej - brak chronologii, czas od razu wypływa. W Kamerdynerze trzeba się temu przyjrzeć. Są takie elementy, które powodują, że rzeczywiście zaczynamy się zastanawiać nad tym, jak czas funkcjonuje $w$ filmie i co on robi z bohaterami. Przyznam, że odkryciem dla mnie było - kiedy tuż przed naszą rozmową kolejny raz obejrzałam Kamerdynera - po co są grzechotki w scenie zabójstwa Petera Schmidta. Gdy uświadomiłam sobie, że takie same grzechotki towarzyszą narodzinom Mateusza Krolla, pomyślałam, że jednym z elementów tego filmu jest czas, ale nie czas pojmowany tylko jako coś, co porządkuje historię, raczej jako początek i koniec. Podobnie jest $w$ jednej z pierwszych scen, kiedy Mati jest chrzczony. Zdecydował się Pan wtedy podzielić kadr na pół, w jednej części mamy obrzęd chrztu, a w drugiej moment śmierci. Takiego napięcia między początkiem i końcem nie ma w Magnacie, ale za to w Magnacie bardzo wyraźnie zaznacza Pan daty. W Kamerdynerze, jeżeli daty się pojawiają, to w bardzo subtelny sposób, zmiana czasoprzestrzeni dokonuje się raczej w obrazie: idzie grupa dzieci z tornistrami, nagły wystrzał pocisku i to jest sygnał dla widza, że jesteśmy w nowym czasie.

F.B.: Oba te filmy są troszkę inaczej opowiadane, inną techniką filmowania. Kamerdyner jest bardzo radykalnie przeze mnie filmowany. Od początku powiedziałem sobie: „robię film epicki”. Przy Magnacie wiedziałem jedną rzecz: że ja nie mogę sobie pozwolić na tego typu stwierdzenia, bo za dużo elementów musiałbym wyrzucić. Natomiast w Kamerdynerze tych elementów nie było aż tak wiele i ta epika mogła je uporządkować na zasadzie wolnego przepływu czasu. Ze zmianą pór roku, zmianą upływających lat, zdarzeń historycznych. Jest to opowiadane w tym samym rytmie epickim, długimi ujęciami i w szerokich planach. Natomiast co do Magnata wiedziałem, że muszę go tylko opowiedzieć, że na założenia estetyczne nie mam tam miejsca, bo będę się musiał ograniczać. A jak mówię, chciałem zrobić film tak szeroki, że żadne ograniczenie nie wchodziło tutaj w rachubę. Ewentualnie 
dodawanie - mnożenie sensów, dodawanie punktów widzenia. Natomiast w kontekście, że tak powiem, zawartości faktograficznej Kamerdyner jest skromniejszym filmem niż Magnat. Kamerdyner też może robić wrażenie dużego filmu przez to, że to są szerokie plany, że to są długie ujęcia, że to są różne miejsca, że ten upływający czas, ta tocząca się wolno historia... Ale w sensie takich moich zadań Kamerdyner był skromniejszym filmem. Magnat pewne rzeczy akcentował, natomiast w epice się niczego nie akcentuje, to zależy od widza, co sobie wybierze, czy ten fragmencik, czy ten, czy to, czy tamto go zainteresuje. Ja montażem nie pomagam. W sensie spełnienia założenia artystycznego większą wolność miałem w Kamerdynerze niż w Magnacie. W Magnacie całkowicie podporządkowałem się historii. Kiedy operator zaczynał coś mówić, to mu odpowiadałem: „Stary, tu jest ważna wyłącznie narracja, bo jeżeli zaczniemy ingerować w narrację i ją zaczniemy interpretować już tutaj, na planie, to się nie wypłacimy”. Dlatego wziąłem Piotrka Sobocińskiego ${ }^{26}$, a nie innego operatora, który był znany z fantastycznych zdjęć, ale też z takiego strasznego pieszczenia. A ja powiedziałem, że nie mogę na to sobie pozwolić, żeby ktoś przy pomocy Magnata starał się, nie wiem, dostać Oscara za zdjęcia, tymczasem ja nie opowiem historii.

I.T.J.: A relacja pomiędzy światłem i cieniem? Ona zwraca uwagę, bo w zasadzie od samego początku, od pierwszych kadrów, kiedy widać chałupę, z której wybiega rodząca kobieta, widzimy ostre światło. Ten dom jest mocno oświetlony, do tego cienie, które rzucają drzewa. W zasadzie duża część historii jest opowiadana w ten sposób. Mamy też liczne sceny, które dokonują się przy oknie $\mathrm{z}$ intensywnym światłem z zewnątrz. Niektóre sceny rozgrywane są $z$ kolei $w$ intensy wnym cieniu do tego stopnia, że trudno dostrzec twarze.

F.B.: Tak, to artystyczny wkład operatora, dla którego modelem były obrazy pewnego szwedzkiego malarza. Pod nie to robiliśmy. Mnie się to bardzo spodobało, powiedziałem: „tak”. Pierwsze ujęcie znałem, wiedziałem, jakie

26 Piotr Sobociński (1958-2001) - operator filmowy, nominowany do Oscara za zdjęcia do filmu Trzy kolory. Czerwony (1994) w reżyserii Krzysztofa Kieślowskiego. Z Filipem Bajonem współpracował również przy realizacji filmów: Bal na dworcu w Koluszkach oraz Pension „Sonnenschein”. 
będzie, zanim znalazłem miejsce zdjęciowe. Szukałem miejsca zdjęciowego pod wyobrażenie tego pierwszego ujęcia. Powiedziałem, że takie musi być i nie ma o czym gadać. Jak znalazłem, po długich, trzytygodniowych poszukiwaniach tej wioski, to powiedziałem: „No tak, to tu, to tu możemy kręcić, bo wszystko się zgadza”. Obróbka scenograficzna nie zajęła dużo czasu. W normalnych warunkach po prostu zbudowałbym taki dom gdzieś w jakimś miejscu w plenerze i zrobił swoje. Chociaż nie wiem, czy to by się udało, bo jednak musiała być w tle wioska. Szukałem czegoś takiego.

\section{I.T.J.: Czymś, co porządkuje ten film od tego pierwszego kadru, jest relacja pomiędzy światłem i cieniem, ale też bardzo często pojawiają się pędzące konie.}

F.B.: Tak.

\section{I.T.J.: Czy to też sposób na pokazanie upływającego czasu?}

F.B.: Na to pytanie nie odpowiem. Mieliśmy ten materiał nakręcony... Zresztą tam, w tym miejscu, gdzie kręciliśmy, a kręciliśmy w świecie pełnym, tam było wszystko. Były stajnie, były konie, był pałac, był padok, były stodoły, była ta droga, jak myśmy to nazywali: archetypiczna, pruska. Bo takie były. Zresztą na okładce pamiętników Otto von Bismarcka jest takie ujęcie, ikona streszczająca Prusy: taka droga właśnie, na jakiej myśmy kręcili. Taka piaszczysta i tak dalej, z drzewami rosnącymi. A ja jeszcze kiedyś, przedtem, pojechałem z żoną na Warmię. Długo szukaliśmy drogi na Wzgórza Dylewskie i w pewnym momencie wjechaliśmy w taką pruską drogę z drzewami stojącymi tuż przy asfalcie, i ta droga tak zakręcała, że właściwie wyglądała, jakby to było jedno wielkie pomieszczenie z drzew zrobione. „Słuchaj - mówię - tutaj można by zrobić fantastyczny obiad”. Kiedy zobaczyłem, że jest tam też aleja, z drugiej strony pałacu, to od razu do mnie tamten pomysł wrócił. Tylko $\mathrm{w}$ ramach działania $\mathrm{z}$ przestrzenią niezauważalnego dla widza; stół, przy którym bohaterowie siedzą, ma długość dziewięciu metrów. Kazałem zrobić taki stół. To nie jest normalny stół. Chodziło o to, żeby odległości pomiędzy siedzącymi były inne. I to są takie małe działania budujące epickość tej opowieści. Parę scen pozostało nienakręconych, ale bez specjalnego żalu. 
I.T.J.: Wracając jeszcze do czasu, subtelniej jest on pokazany w Kamerdynerze niż Magnacie...

F.B.: No ale jeszcze ujęcie, któreś z kolei, piąte czy szóste, otwierające sekwencję: kulawy ustawia zegary.

I.T.J.: Tak, tak, właśnie o tym chciałam powiedzieć. Ustawianie zegarów, dodatkowo pojawia się dźwięk zegarów. My je słyszymy, one ciągle pracują. Element, który wskazuje, że czas upływa i dotyka bohaterów, rozgrywa się też w dialogach. Bohaterowie komentują: „kończy się nasza epoka”. Różne postaci w różnym momencie zaczynają ten fakt dostrzegać. Pierwsza widzi to Gerda von Krauss. Jej mąż dostrzega to dopiero na końcu historii. Zastanawiałam się w kontekście refleksji dotyczącej pojęcia końca nad taką rzeczą, która bardzo mi się skojarzyła z filmem Hiroszima moja miłość ${ }^{27}$...

F.B.: Lubię ten film.

I.T.J.: Lubi Pan? No właśnie, w Pańskim filmie są co najmniej dwa takie momenty, które bezpośrednio konfrontują dużą historię z małą historią, dramat społeczny $z$ dramatem jednostki. Raz mamy to w scenie, w której z Bazylim Miotkem rozmawia jego żona i zaniepokojona mówi mu, że Mateusz i Marika „mają się ku sobie”, na co on, po doświadczeniach wojny, mówi: „Ula, ja widziałem tyle gówna na świecie, że może w tej miłości jest jakieś odkupienie”. Druga scena to rozmowa Hermanna von Kraussa z mężem Marity. Siedząc w samochodzie, rozmawiają o katastrofie pod Stalingradem i katastrofie małżeństwa Marity. Czy tak jak Resnais stara się Pan te dwa dramaty zrównoważyć, ten z wielkiej historii i ten prywatny?

F.B.: To zawsze jest pewne pytanie, bardzo poważne, tylko ja je traktuję na poziomie roboty, bo ono się naprawdę pojawia na poziomie roboty. Czyli jaką samoświadomość historyczną mają bohaterowie. Generalne to jest

27 Hiroszima moja miłość, reż. Alan Resnais, Francja 1959. 
pytanie, czy człowiek wie, w jakim świecie uczestniczy. Kiedy zasadniczo nie możemy się posługiwać kategorią postępu, nawet tak pomocniczo, bo moim zdaniem ta kategoria nie istnieje, dlatego jest bezużyteczna. Jeżeli używamy kategorii postępu, to wiemy, w jakim świecie uczestniczymy: w świecie pary, w świecie samochodów, w świecie elektryczności, w świecie komputerów i tak dalej. Ale to jest złudna kategoria, intuicyjna kategoria raczej. Bardziej mnie interesuje... no dobra, niektórzy uważają, że najważniejsze są relacje rodzinne, ale ja uważam, że nie są najważniejsze, takie jest moje głębokie przekonanie. W związku z tym - jakie kategorie są najważniejsze? I to trzeba rozwiązać właśnie na poziomie budowania bohatera, jakie on ma poczucie, przeczucia i czy wie, w jakim świecie uczestniczy, bo większość ludzi tego nie wie. To jest moje generalne spostrzeżenie. Uczestniczą w pewnych faktach, spostrzeżeniach, ale nie wiedzą, co ten świat znaczy. Jeżeli mam takiego bohatera, który dochodzi do tego, co ten świat znaczy - ktoś dochodzi wcześniej, ktoś dochodzi później - no to ten bohater minie bardzo interesuje. Tylko mówię: to jest na poziomie rozmowy z aktorem. Jeżeli bohater uczestniczy w życiu rodzinnym i w życiu, w emanacji świata, która do niego dochodzi, rozumie pewne prądy czy to, co jest pod ziemią, czy to, co gdzieś drży, wibruje, to mamy pewną równowagę między uczestnictwem w życiu tak zwanym normalnym i uczestnictwie w życiu metafizycznym, czyli, powtarzam, jest tu pewna równowaga. Tylko uczestnictwo w życiu metaforycznym musi być specjalnie pokazane, żeby nie tworzyło natrętnej symboliki i nie było rodzajem przemądrzalstwa.

\section{I.T.J.: Dlaczego Mati zostaje?}

F.B.: Mati zostaje moim zdaniem dlatego, że uznał swoje życie w nieswojej rodzinie za realne, za prawdę.

I.T.J.: Skoro tak, to wydaje mi się, że Pan tę decyzję bohatera zapowiada trochę wcześniej. Kiedy Mateusz ma wyjeżdżać do gimnazjum, rozmawia z Bazylim i ten mu mówi: „Rozejrzyj się, to jest twoje miejsce”. Zdaje mi się, że on mu w ten sposób wkłada pewną świadomość, z którą chłopak potem żyje.

F.B.: Tak. 
I.T.J.: Dla Mateusza przełomowym momentem, ale też momentem kończącym w sposób symboliczny jego życie, był strzał, było zabójstwo nauczyciela muzyki, którego dokonał.

F.B.: Uhm.

I.T.J.: Jego życie zaczyna się przy dźwięku grzechotek i szumy grzechotek to jego życie zamykają.

F.B.: Japońskie ujęcie... tak je zawsze nazywałem. Jak z japońskiego filmu.

Wywiad autoryzowany, przeprowadzony 18 marca 2020 r. w Wytwórni Filmów Dokumentalnych i Fabularnych $w$ Warszawie 